\title{
Distance learning of specialists in information and library activities in Russia and Kazakhstan
}

\author{
Madina Gazizovna Zhardemova ${ }^{11}$, Valentina Alekseevna Gorbacheva ${ }^{2}$, Diana \\ Aleksandrovna Gorbacheva ${ }^{3}$, Aleksander Aleksandrovich Gorbachev ${ }^{4}$, and Olga Igorevna \\ Vorozheikina $^{2}$ \\ ${ }^{1}$ Moscow State Institute of Culture, Department of Pedagogy, Psychology and Philosophy, Moscow, \\ Russia \\ ${ }^{2}$ West Kazakhstan Innovation and Technology University, Uralsk, Kazakhstan \\ ${ }^{3}$ Krasnodar State Institute of Culture, Krasnodar, Russia \\ ${ }^{4}$ Makhambet Utemisov West Kazakhstan University, Uralsk, Kazakhstan
}

\begin{abstract}
The article presents an analysis of opportunities of distance education organization for future librarians in the universities of Kazakhstan under the conditions of the Corona VIrus Disease-19 pandemic. These opportunities of distance and media education were actualized in the context of the coronavirus pandemic due to self-isolation of students. The process of modern library staff professional education has always been ahead of many humanities in the aspect of implementation of new information and communication technologies in the educational process with its focus on values of digital and virtual educational environment. In modern conditions, during the transition from an industrial society to a post-industrious information society of knowledge and innovations, the issues of extensive introduction of digital technologies have become more central in order to overcome the gap between the current need for information, the study of national and foreign experience, the tasks of new socio-cultural practices and the existing level of professional education of librarians. Therefore, the purpose of this study is to reveal the features of the formation of a culture of online distance learning, to identify positive experiences that pose a universal response to the crisis of pedagogical and psychological education, civil, personal and ethnic identities (ideals, beliefs, worldview) in the formation of professional competencies of librarians. The authors used the following scientific research methods: study of electronic content, observation, questionnaires, test polls, the Computer Assisted Web Interview method, conversations, focus groups, content analysis and others. In this study, the authors structured and characterized the main directions of the development of pedagogical culture of distance education, identified a positive experience, which poses a universal response to the crisis of librarian education. We analyzed the totality of objective, methodological, organizational and evaluative components of the system of distance education. The main attention is paid to the issues of organizing the educational process of distance education for librarians in the Republic of
\end{abstract}

${ }^{1}$ Corresponding author: $\underline{\text { mmukanova@mail.ru }}$ 
Kazakhstan and in Russia, student surveys, which showed that with a large selection of foreign and national platforms, they give preference to national educational programs developed by leading Kazakhstani researchers and teachers. An educational and pedagogical analysis of the leading platforms has been carried out. In the conclusion, the positive aspects of distance education are revealed and recommendations are given to organize and to improve the educational process and the development of the distance education system more effectively under the conditions of the pandemic and self-isolation.

Keywords: professional librarian education, digital educational environment, educational environment, distance education, online course, educational platforms.

\section{Introduction}

Distance education in the training of library science students in universities of Kazakhstan is becoming particularly relevant in the context of the pandemic, as this system helps to respond to the needs of society adequately and flexibly. It ensures the implementation of the constitutional right to education of every citizen of the country, but only in a way of combination of classical forms and methods of building students' professional competencies.

Our analysis of scientific and practical literature on the distance education system shows that the problem generally corresponds to the logic of the development of the education system and the present-day society, aggravated by a coronavirus pandemic that has set new challenges for education.

Gorbacheva and Gorbachev characterize such advantages of distance education as flexibility, modularity, economic efficiency, a new role of the teacher, etc. [1].

Sandars, Correia, Dankbaar, and Jong note that teachers can use the resources of the Learning Management System [2]. These are platforms for communication, content uploading and rating. The systems use built-in analytics to monitor student progress and identify those who need special support [2].

Gritsai believes that new educational media technologies require a rational approach to provide a smart mix of traditional and innovative forms of education [3].

Berger, Belyaev, Tarkhov and some other authors conclude that the digital educational environment is a part of the electronic information and educational environment. Electronic information and educational environment is a system that includes: material and technical, human resources; ensuring the automation of management and pedagogical processes, coordinated use of information; availability of a regulatory and organizational base, technical and methodological support [4-6].

Zhardemova analyses the specifics of modern higher library professional education in the Republic of Kazakhstan [7].

The issues of business reputation and management of the formation of the social and pedagogical image of higher educational institutions, including those in crisis conditions, are disclosed and described by Gorbacheva, Gorbachev, Skripkina, Turavets [8].

Yu.S. Braun notes that the definitions of "distance" and "electronic" are often used interchangeably when defining and describing online courses, which is incorrect to his mind [9]. Distance education is provided or operated at a distance, while electronic education exists only in a digital form (for example, an electronic book) or is carried out by means of network technologies (for example, email or e-business). 
Sandars, Correia, Dankbaar, and Jong identify the problems that organizations face in providing open online education and characterize the possibilities for their solution [2].

Gable [10] and Barakhsanova, Malgarov [11] define an online course as a type of e-learning built on the basis of pedagogical principles, implemented on the basis of technical means of modern information technologies and representing logically and a structurally completed educational unit, methodologically provided with a unique set of systematized electronic teaching and control tools.

Therefore, the purpose of this study is to reveal the features of the formation of a culture of online distance learning, to identify positive experiences that pose a universal response to the crisis of pedagogical and psychological education, civil, personal and ethnic identities (ideals, beliefs, worldview) in the formation of professional competencies of librarians.

\section{Methods}

The authors used the following scientific research methods: study of electronic content, observation, questionnaires, test polls, the Computer Assisted Web Interview (CAWI) method (web interviews), conversations, focus groups, content analysis and others.

\section{$3 \quad$ Results and discussion}

The results of our research organized and held in recent years [1] have confirmed the fact that the distance education system is designed to fulfill the following socially and culturally significant functions:

- improving the level of public education and the quality of education;

- meeting the needs of the population in educational services;

- meeting the country's needs for high-quality trained specialists;

- increasing the social and professional mobility of the population, its entrepreneurial and social activity, worldview and level of self-awareness;

- promoting the preservation and enhancement of knowledge, human and material potential accumulated by the national system of higher education;

- development of a unified educational space that supports the provision of information opportunities.

As a rule, the possibilities of digital tools are usually represented by software products for management and organization of the educational process, presentation of educational materials, documentation of professional actions, and recording achievements in digital format. Digital footprints are defined as all the actions of students in the Internet space left as an impression, including presentations, blogs, discussions in various simulation development environment formats, video facts, etc. The main system-forming components of digital education are as follows: digital educational environment, digital way of organization of the educational process, digital processes of knowledge evaluation testing, digital technologies of teaching and learning, digital content of education, digital technologies of interaction, digital resources.

The Law of the Republic of Kazakhstan "On Education" [12] (Chapter 1, Article 1), defines a distance technology as a purposeful and methodically organized management of educational and cognitive activities of students who reside far from educational organizations, through using different electronic and telecommunications devices. 
Forced quarantine, longer holidays and isolation, with the incapability of visiting cinemas, shopping and entertainment centers, clubs and sections raise the problem of organization of students' useful leisure time.

Our surveys of students showed that due to the timely set-up of unique educational platforms by leading Kazakh researchers, methodologists and teachers, the respondents rate highly 16 domestic educational programs with a large selection of foreign and domestic platforms. We will conduct an educational and pedagogical analysis of the leading platforms:

- "Bilimland.KZ" is an educational platform based on the advanced achievements of the global leaders in e-learning. This is the largest collection of the most contemporary educational content from the global developers for teachers, students and parents.

- "Openu.kz" (Open University of Kazakhstan) is an online educational platform that provides access to online courses from leading universities and teachers of the country. There are more than 170 courses on the humanities, engineering and business available for users. The books translated within the project "ZhanagumanitalykbilimKazaktilindegi 100 zhanaokulyk" are also available on the website.

- "Academia.kz" is an educational platform for teachers and parents. It contains a large collection of research experiments, methodological materials and pedagogical literature for teachers' and parents' creative activity.

- "Academicearth.org" is an aggregator of courses of leading US universities. The site allows you to take courses from such universities as Cornell, Columbia, Harvard, Dartmouth, Princeton, Stanford, Yale and some others.

- "Googleartinstitute" is an online platform with the access to works of art from around the world. At the moment, it is possible to view the collection of more than 32,000 items from 32 world museums and art exhibitions, including the Metropolitan Museum of Art (New York), the Uffizi (Florence) and the Tate Contemporary Gallery (London).

- "MIT OpenCourseWare" presents educational materials of the University of MIT in engineering and IT.

- "TED-Ed-TED" was created for educational purposes and organized on the principles of topics with questions and tests.

- "National Geographic Kids" is a popular National Geographic content for children. It has a convenient website and contains the content for learning about nature and the planet [13].

The Zoom has become one of the main educational resources during the coronavirus pandemic in the universities of the Republic of Kazakhstan and the Russian Federation (M. Utemisov West Kazakhstan University, West Kazakhstan Information Technology University, Moscow State Institute of Culture, Krasnodar State Institute of Culture, and others).

For example, the first-year students who entered the educational program on Library Science began their 2020-2021 academic year in the conventional classroom form, with the attendance of lectures. Seminars and practical classes were organized in the form of distance education.

Much attention was paid to the organization and conduct of interactive lectures, which due to specific information and its cognitive content, have an emotional connotation strengthened by video and audio materials, computer graphics and presentations. We concluded that multimedia, as compared to the common verbal methods of presenting knowledge, makes it possible to affect several perception systems simultaneously because information is transmitted in a variety of sensations, affecting long-term memory. As a result, it strengthens and activates the process of new knowledge assimilation. 
The correspondence (external) training based on distance education technology is organized as follows.

Table 1. Forms of distance education.

\begin{tabular}{|l|l|l|l|}
\hline \multicolumn{1}{|c|}{$\begin{array}{c}\text { Source of } \\
\text { educational } \\
\text { information }\end{array}$} & \multicolumn{1}{|c|}{ Means of delivery } & $\begin{array}{c}\text { Methods of } \\
\text { communication with } \\
\text { fellow students }\end{array}$ & $\begin{array}{l}\text { Technical means of } \\
\text { communication with } \\
\text { the teacher }\end{array}$ \\
\hline $\begin{array}{l}\text { Video, audio, } \\
\text { printed materials }\end{array}$ & $\begin{array}{l}\text { E-mail, learning } \\
\text { platforms: Zoom, Moodle, } \\
\text { Microsoft Teams; } \\
\text { messengers: WhatsApp, } \\
\text { Viber, Telegram, etc. }\end{array}$ & $\begin{array}{l}\text { Audio-Video } \\
\text { conferences }\end{array}$ & $\begin{array}{l}\text { Phone, tablet, } \\
\text { computer, laptop }\end{array}$ \\
\hline $\begin{array}{l}\text { Training networks, } \\
\text { special online } \\
\text { databases }\end{array}$ & $\begin{array}{l}\text { E-mail, learning } \\
\text { platforms: Zoom, Moodle, } \\
\text { Microsoft Teams; } \\
\text { messengers: WhatsApp, } \\
\text { Viber, Telegram, etc. }\end{array}$ & $\begin{array}{l}\text { Audio-Video } \\
\text { conferences }\end{array}$ & $\begin{array}{l}\text { Phone, tablet, } \\
\text { computer, laptop }\end{array}$ \\
\hline
\end{tabular}

Training in higher education institutions of Kazakhstan in this period is carried out mainly in the distance format. In pedagogical, IT, social and humanitarian areas $100 \%$ of lectures and seminars are delivered in a remote format. In the natural, technical, agricultural, medical and art fields some $70 \%$ of lectures and seminars are conducted in an online format, and laboratory and practical classes are conducted in a conventional format under strict compliance with enhanced sanitary measures.

\section{Conclusion}

1. The basis of online education is a digital educational environment that is based on a system of educational platforms, with the use of software products for the management and organization of the educational process.

2. Being involved in the educational process in various forms in the distance learning system, the components of which are electronic (digital) educational resources, the student becomes the subject of communication with the teacher and other students. This is one of the major factors of development of the student's independence, autonomy and creativity in different educational activities.

3. The educational technology is based upon certain content and must meet the requirements of its presentation. The content of the knowledge proposed for teaching and learning is accumulated in special courses and modules specially designed for the needs and specific character of online education of students, and it should be based on the national educational standards and requirements approved in the country, as well as in educational tools: data and knowledge banks, video libraries, etc.

4. Students having a large selection of foreign and domestic educational platforms, also give preference to domestic, scientifically based (without political bias) educational programs that cover a variety of sciences, disciplines and areas.

5. To bridge the gap between the actual needs for information in the context of new socio-cultural practices and the existing level of training of librarians in universities, an educational environment should be created for organization of the full and effective student's access to educational information, educational resources provided by means of 
remote access in online mode while using the Zoom, the Moodle, the Microsoft Teams and Internet resources.

The advantage of distance education is becoming obvious. The development of distance education technologies has become particularly relevant for the educational system during the pandemic under the influence of the process of formation and rapid development of new digital means and tools of information exchange between participants in the educational process.

Despite all the advantages of this kind of education, surveys of students and teaching staff, schoolchildren and parents, show that most of the respondents still want to return to live communication with teachers and students in the form of conventional education in a classroom.

\section{References}

1. V.A. Gorbacheva, A.A. Gorbachev, Osnovy professionalno-pedagogicheskoi deyatelnosti prepodavatelei vuzov kultury i iskusstv [Fundamentals of Professional and Pedagogical Activities of Teachers of Universities of Culture and Arts] (Publ. House MGUKI, Moscow, 2009)

2. J. Sandars, R. Correia, M. Dankbaar, P. de Jong, et al., MedEdPublish, 9(1), 82 (2020). https://doi.org/10.15694/mep.2020.000082.1

3. L. Gritsai, Media Edu. (Mediaobrazovanie), 60(4), 627-635 (2020). https://doi.org/10.13187/me.2020.4.627

4. G. Berger, Remarks, in Media and Information Literacy: Educational Strategies for the Prevention of Violent Extremism. United Nations Headquarters, February 10, 2017, New York, United States (2017). Accessed on: July 17, 2021. [Online]. Available: https://www.youtube.com/watch?v=tmPKRY8Y-J8

5. M.I. Belyaev, V.M. Vymyatnin, S.G. Grigorev, et al., Teoreticheskie osnovy sozdaniya obrazovatelnykh elektronnykh izdanii [Theoretical Foundations of Compiling Educational Electronic Publications] (Publishing House of Tomsk University, Tomsk, 2015)

6. S.V. Tarhov, Media Edu. 4, 66-80 (2016)

7. M. G. Zhardemova, Digital Culture of Future Librarians in the System of Higher Cultural Education, in Proc. Int. Conf. "Scientific Research of the SCO countries: Synergy and Integration" December 8, 2020, Beijing, PRC, 34 (2020)

8. D.A. Gorbacheva, A.A. Gorbachev, A.V. Skripkina, N.R. Turavec, J. Hist., Cult. Art Res. 6(4), 1351-1357 (2017). https://doi.org/10.7596/taksad.v6i4.1192

9. Yu.S Braun, Inf. and Edu. 2, 71-77 (2016)

10. E. Gable, Tsifrovaya transformatsiya shkolnogo obrazovaniya. Mezhdunarodnyi opyt, trendy, globalnye rekomendatsii [Digital Transformation of School Education. International Experience, Trends, Global Recommendations], in P.A. Sergomanov (ed.) (National Research University "Higher School of Economics", Institute of Education, Moscow, 2019)

11. E.A. Barahsanova, I.I. Malgarov, Prob. Contemp. Pedag. Edu. 61(2), (2018)

12. The Law of the Republic of Kazakhstan dated 27 July, 2007 No. 319-III "On Education". Accessed on: July 17, 2021. [Online]. Available: https://adilet.zan.kz/eng/docs/Z070000319 
13. Kakie obrazovatelnye platformy dostupny onlain [What educational platforms are available online]. Accessed on: July 17, 2021. [Online]. Available:

https://24.kz/ru/news/obrazovanie-i-nauka/item/381149-kakie-obrazovatelnye-platform y-dostupny-onlajn 